\author{
Рязанцев Лев Васильович \\ доцент кафедри кіно-телемистеитва, \\ Київький національний університет \\ культури і мистецтвв, \\ Київ, Украӥна \\ l.ryazancev2016@gmail.com
}

\title{
ДОСЛІДЖЕННЯ ФУНКЦІЇ ЦИТАТИ В КІНОМУЗИЦІ
}

Мета роботи. Здійснити аналіз функцій цитати в кіномузиці в системі організації звукового рішення фільму, виявити особливості їі застосування в різних фільмах та визначити способи ії реалізації. Методологія дослідження передбачає застосування аудіовізуального аналізу кінофільмів, що дозволить перейти до розуміння основних функції цитати в кіномузиці. Наукова новизна дослідження в тому, що вперше сформовані основні принципи застосування музичних цитат в кінофільмі та показано їх вплив на звукове вирішення кінофільму. Висновки. Вдаючись до цитування, композитор і режисер повинні подбати про те, щоб глядач їх упізнав. Цитата привносить емоційні й смислові асоціації. В німому фільмі музична ілюстрація складена виключно з музичних цитат. Музичні цитати можуть виконувати різноманітні функції: підкреслювати трагізм сцени, використовуватись як іронічний контраст. Також цитата може бути застосована як драматичний елемент і музичний символ, може створювати пародію, характеризувати певний персонаж. Таким чином, аналіз матеріалу про цитату в фільмі дозволив автору статті сформувати систему понять про цитату в кіномузиці з обговоренням іiі застосування, що має суттєве значення для практики звукового вирішення кінофільму.

Ключові слова: кіномузика, цитата в кіномузиці, кінофільм, музика.

Рязанцев Лев Васильевич, дочент кафедри кино-телеискусства Киевский национальный университет культуры и искусст, Киев, Украина

Исследование функций цитаты в киномузыке

Цель работы. Осуществить анализ функций цитаты в киномузыке в системе организации звукового решения фильма, выявить особенности ее применения в различных фильмах и определить способы ее реализации. Методология исследования предполагает применение аудиовизуального анализа кинофильмов, позволит перейти к пониманию основных функций цитаты в киномузыке. Научная новизна исследования состоит в том, что 
впервые сформированы основные принципы применения музыкальных цитат в фильме, и показано их влияние на звуковое решение фильма. Выводы. Прибегая к цитированию, композитор и режиссер должны позаботиться о том, чтобы зритель их узнавал. Цитата привносит эмоциональные и смысловые ассоциации. В немом фильме музыкальная иллюстрация составлена исключительно из музыкальных цитат. Музыкальные цитаты могут выполнять различные функции: подчеркивать трагизм сцены, использоваться как иронический контраст. Также цитата применима как драматический элемент и музыкальный символ, может создавать пародию, характеризовать определенный персонаж. Таким образом, анализ материала о цитате в фильме позволил автору статьи сформировать систему понятий о цитате в киномузыке с обсуждением её применения, что имеет существенное значение для практики звукового решения фильма.

Ключевые слова: киномузыка, цитата в киномузыке, фильм, музыка.

Riazantsev Lev, Associate Professor of the Department of Cinema and Art, Kyiv National University of Culture and Arts, Kyiv, Ukraine

\section{The function of quotation in cinematic music}

The purpose of the article is to analyze the functions of quotation in the system of sound design of a motion picture; to reveal the features of its application in various films; to determine the ways of its realization. The research methodology consisted in the application of audiovisual analysis of motion pictures, which allowed for understanding the basic functions of quotation in cinematic music. The scientific novelty of the work lies in shaping the basic principles of the application of music quotations in films and distinguishing their influence upon the sound design of the motion picture. Conclusions. When resorting to quotations, the composer and director ought to ensure that the viewer recognizes them. Quotations carry emotional and semantic associations. In silent movies, musical illustration is composed exclusively of musical quotations. Musical quotations can perform various functions: emphasize the tragedy of the scene, be used as an ironic contrast. Quotation is also applicable as a dramatic element and a musical symbol; it can create a parody, and be descriptive of a certain character. Thus, the analysis of the material about quotation in motion picture allowed the author of the article to form a system of concepts regarding quotation in cinematic music with a discussion on its application, which is essential for the practice of sound design of films.

Key words: cinematic music, quotation in cinematic music, film, music. 
Вступ. Усі мистецтва, що існують у часі та просторі, так чи інакше пов'язані зі звуком і музикою. Мистецтва, в яких музика відіграє найбільш суттєву роль $є$ кіно, телебачення, відео. Будь-яке художнє явище рано чи пізно створює свою власну теорію, що формує його основні проблеми, його естетичні та конструктивні принципи, у повній мірі це стосується й існування цитати в кіномузиці. Стаття «Дослідження функції цитати в кіномузиці» відповідає вимогам напряму дослідження «Секції звукорежисури» кафедри кінотелемистецтва «Роль кіномузики в створенні звукового вирішення фільму», що також відповідає темі наукового дослідження КНУКіМ «Трасформаційні процеси в культурі та мистецтвах України»

Аналіз досліджень і публікацій. Роль кіномузики в фільмі розглядалась С. Ейзенштейном ще на початку появи звукового кіно в працях «Будущее звукового фильма. Заявка» [7, с. 315-317] і «Вертикальный монтаж». [7, c. 189-268]. Останнім часом ця тема розробляється сучасними авторами. Так, в монографії Горпенко В. Г. [2, с. 71-110], яка присвячена проблемам режисури екранних мистецтв, в третьому томі розглядаються принципи музично-зорового монтажу. Про функції кіномузики йдеться в главі «Функції звукового ряду в кіно» у Зофії Лісси [4, с. 133-285]. У Маньковського В. С. [5, с. 28-49] в розділі «Особенности художественной передачи звука» розглядається роль музики в художніх фільмах. Розлогов К. Є. [3, с. 120-197] розглядає шляхи аудіовізуального синтезу. Ролі лейтмотивів присвячена стаття автора «Техніка лейтмотивів в кіномузиці» [6, с. 124-130]. Треба підкреслити, що проблема цитати в кіномузиці в наукових дослідженнях у всіх аспектах не достатньо висвітлена. Перед нами стає проблема, яку висуває практика звукового рішення фільму, тому ми повинні детально зупинитися на проблемі функцій музичної цитати в кіномузиці.

Мета статті - дослідити складові функції цитати в кіномузиці в організації звукового вирішення фільму, проаналізувати особливості іiі застосування в різних фільмах та визначити способи ії реалізації.

Виходячи з цього були поставлені конкретні завдання, а саме:

- $\quad$ дослідити, що музична цитата привносить у кінофільм;

- проаналізувати, які функції може виконувати музична цитата у фільмі;

- систематизувати матеріал і сформулювати систему понять про цитату.

Виклад основного матеріалу. Перед усім визначимося, що ж таке «цитата». ЦИТАТА (пізньолат. citatio, від лат. Cito - «зрушую», «викликаю») це - «невеликий уривок з літературного, музичного, наукового чи будь-якого іншого опублікованого твору. Використовується іншою особою в своїй праці 3 обов'язковим посиланням на автора й джерело цитування 3 метою підтвердити чи розширити власне твердження» [1, с. 231]. 
У музичну ілюстрацію фільму досить часто включаються маленькі й великі уривки знайомих нам музичних творів. Це можуть бути частини з відомих симфонічних творів, опер, інструментальних або камерних музичних п’єс та ін. Вони можуть вплітатися в драматичну дію фільму будь-яким чином.

Якщо ми хочемо вичерпно висвітлити різноманітні проблеми, які ставить перед нами практика звукового рішення фільму, ми повинні детально зупинитися i на проблемі музичної цитати в фільмі. Вдаючись до такого цитування, композитор i режисер повинні подбати про те, щоб глядач їх упізнав. Цитата, незалежно від змісту сцени, де вона застосована, привносить емоційні й смислові асоціації, отже, додає до кінокадрів щось своє, говорить, якщо можна так висловитися, сама за себе. Зіткнення обох змістів, музичного та образотворчого, додає щось нове епізоду в цілому.

У німому кіно музична ілюстрація, складена виключно з музичних цитат, аж ніяк не сприймалася як нанизування цитат, а як нормальний супровід кінофільму. I тільки місце, яке встановилося для музики в звуковому кіно, навчило публіку розбиратися в автентичності музичної «цитати» і допомогло сприймати і розуміти іiі по іншому. Режисер або композитор вводять цитату, розраховуючи на певні асоціації, які вона має викликати. Впізнаючи цитату, кіноглядач розуміє іiі функцію, іiі завдання в цій сцені.

Музичні цитати можуть виконувати різноманітні драматургічні функції, але вони не можуть служити тільки фоном для будь-якої сцени. Музична цитата може бути пов'язана з внутрішньокадровим виконанням або відтворенням, як наприклад, у фільмі «Блиск» (Режисер: Скотт Хікс. Композитор: Девід Хиршфелдер) про долю одного з кращих піаністів свого часу Девіда Хелфготта, де виконується музика Фредеріка Шопена, Ференца Ліста. У сцені вбивства в фільмі «Дівиця Розмарі» (Режисер: Ріхард Тіле. Композитор: Ноель Шульце) 3 показаного в кадрі радіоприймача долинає мотивчик Оффенбаха, контраст між цією безтурботної музикою і змістом кадру підкреслює весь трагізм сцени.

Як цитата і одночасно як іронічний контраст діє мотив 3 увертюри до «Лоенгріну» в кінофільмі Чапліна «Великий диктатор» (Режисер: Чарльз Чаплін. Композитор: Мередіт Уіллсон) в сцені, де диктатор грає повітряною кулею, що зображує нашу планету, мотиви Грааля і символічна іграшка (всю земну кулю в руках цього персонажа!) складають моторошний контрапункт антитезу, що дуже легко зрозуміти.

Музична цитата може підкреслити атмосферу навколишнього середовища. Такий прийом використовував Стенлі Кубрик у своєму фільмі «Заводной апельсин» використовуючи увертюру до «Вільгельма Телля» Россіні та Симфонію № 9 Бетховена. Картина складається 3 роздумів про сутність людської агресії на прикладі підлітків, про свободу волі й адекватності 
покарання. Головний герой - харизматичний підліток Алекс (Малкольм Макдауелл), закоханий в музику Бетховена, $є$ ватажком банди, що складається крім нього ще 3 трьох молодих людей, яка займається актами «ультранасилля»: нападами й згвалтуваннями, порушуючи спокій мирних громадян футуристичной Британії [3].

Цитата може виконувати подвійну функцію, а саме служити цитатою для героя фільму й одночасно для глядача, наприклад, у фільмі «Юність Шопена» (Режисер: А. Форд. Композитор: К. Сероцкий) коли Шопен слухає капріс Паганіні. Але вона може бути адресована тільки глядачеві, як в старому фільмі «Пасторальна симфонія», де режисер додає до картини квітучих садів (без участі людей) супровід 3 «Пасторальної симфонії» Бетховена. Таким чином він збагачує сцену усіма тими асоціаціями, які для глядача пов'язані з симфонією Бетховена. Адже ця симфонія стала символом «пасторального» змісту.

Цитата може бути застосована i як драматичний елемент 3 власним висловлюванням. «Ельвіра Мадіган» - шведський художній фільм, знятий в 1967 році за однойменною баладою Юхана Ліндстрем Саксона. Режисер: Бу Відерберга. Композитор: Ульф Бьёрглін. Балада й фільм розповідають про реальні події - історію кохання і смерті датської циркової вершниці Ельвіри Мадіган. У фільмі показано, як закохана пара пустує на весняному лузі під звуки 21 концерту В. А. Моцарта. Музика впливає на настрій цих двох людей, поглиблює його, хоча сама вона безпосередньо з дією не пов'язана.

Тут треба вказати ще на одне особливо тонке застосування цитати, яке стоїть уже на межі музичної символіки: в фільмі «Новий Вавилон» (Режисери: Григорій Козинцев, Леонід Трауберг. Композитор: Дмитро Шостакович), який присвячений Паризькій Комуні. Керуючий магазину «Новий Вавилон» не пропускає нагоди нагадати юній продавчині Луїзі, хто тут господар; коли приходить час, вона не довго думаючи відправляється на барикади ... Тут Шостакович проводить на великих відрізках контрапункт двох цитат - канкану 3 «Орфея в пеклі» Оффенбаха і ... «Марсельєзи». Символіку, закладену в переплетенні цих цитат, неважко зрозуміти: це протиріччя, що пронизують все життя між міщанською ідеологією i революційними прагненнями. Стилістична і жанрова відмінність між цими цитатами ще більше полегшує їх тлумачення. У радянському фільмі «До побачення, хлопчики» (Режисер: Михайло Калик. Композитор: Мікаел Таравердіев) велика цитата 3 масової пісні «Улюблене місто» $€$ символом прощання з рідним містом. Ця пісня може функціонувати як цитата завдяки широкій популярності їі мелодії й тексту.

Цитата може також характеризувати певні тенденції. У радянському фільмі «Петро I» (Режисер: Володимир Петров. Композитор: Володимир Щербачов) з'являються цитати з музики Телемана й інших німецьких музикантів перша пол. 
XVIII ст., твори які в ту пору були прийняті при царському дворі як придворна музика; завдання цитат в даному випадку - охарактеризувати прагнення царя підвищити вплив західної цивілізації в Росії. Оскільки цитати ці можуть впізнати лише деякі кіноглядачі, вони сприймаються більшою частиною публіки просто як музика певного історичного стилю, і для цих глядачів вони мають невелике значення, ніж для тим глядачів, кому відоме походження виконаних уривків.

Музичні цитати слугують іноді й цілям створення пародії. Приклад, такого застосування найрізноманітніших цитат ми знаходимо у фільмі «Вірнопідданий» (Режисер В. Штауде. Композитор Х. Г. Зібер) Мелодії добре відомих німецьких пісень або пруських маршів використовуються в сценах, де слова цитованих пісень викривають брехню показаної сцени, наприклад: «Варта на Рейні» або «Німеччина понад усе», а також «Будь завжди вірний i чесний». Режисер і композитор використовують їх, розраховуючи на асоціацію цитованих мелодій з текстом цих пісень. Теж саме мав на увазі й Федеріко Фелліні в фільмі «Репетиція оркестру». Зрозуміло, що такі цитати знову можуть «грати» тільки в тому випадку, якщо публіка буде правильно їх розпізнавати й коментувати.

Музична цитата в своїй суті може характеризувати певний персонаж. У такій функції застосовується цитата 3 фіналу Дев'ятої симфонії Бетховена в німецькому фільмі «Ми - вундеркінди» (Режисер: Курт Хоффманн Композитор: Франц Гроті). Герой фільму, ліберал і противник фашизму, німець перших років гітлерівського панування, повертається в новорічну ніч з ресторану, де п'яні фашисти дико кричали свої пісні, і включає радіо, звідки лунають благородні звуки заключного хора Дев'ятої. Монтажний стрибок від п'яних голосів до чистого гімну Бетховена створює контраст, який повинен охарактеризувати героя. Насправді, ця цитата могла бути й випадковою, але контраст в музиці обох сусідніх сцен створений, звичайно, навмисно. Тут має місця коментар до світогляду героя.

Цитати у вигляді мотивів 3 народних пісень, навряд чи можна розглядати як цитати в цьому сенсі. Вони не виділяються як такі з загальної звукової течії, а швидше служать для нього музичним матеріалом, що несе асоціації, й таким чином характеризують сцену. Наприклад, це можна простежити в фільмі «Пропала грамота» українського кінорежисера Бориса Івченка, музикальне оформлення Івана Миколайчука. Фільм знято за мотивами однойменної повісті Миколи Гоголя. Героїчна народна комедія з лукавою посмішкою й запальним гумором розповідає про повний пригод шлях козаків Василя та Андрія з Гетьманською грамотою до цариці в Петербург, а після цього - про їхнє щасливе повернення в рідну Диканьку. Фільм має ознаки трагікомедії й карнавалу. 
У фільмі звучать такі пісні:

- Танцювала риба з раком;

- Чорна земля ізорана;

- Розпрягайте, хлопці, коней;

- Благословіть й отець й мати свою дитятю;

- А я бідний, нещасливий (уривок 3 пісні «Там, де Ятрань круто в'ється»);

- Колискова (Гойда, гойда-гой, ніченька іде ...);

- Нумо хлопці до зброї (Ой збиралися орли чайку рятувати ...).

Пісні співали Ніна Матвієнко, В. Ковальська, М. Миколайчук. Бандура Галина Менкуш. Скрипки - брати Чередники. 3 інструментальних творів лунає «Козацький марш» у виконанні оркестру народних інструментів під керівництвом Я. Орлова[6].

Взагалі чіткої межі між музичною цитатою і використанням знайомих народних мотивів провести не можна. На цій межі, наприклад, знаходиться цитата з старовинної англійської «Пісні Еджінкорта» в кінофільмі «Генріх V» (Режисер: Л. Олів'є. Композитор: У. Уолтон), де вона повинна своєю мелодією підкреслити стиль епохи й національного середовища. Фільм починається як постановка п’єси Шекспіра «Генріх V» на сцені театру «Глобус», де глядачі супроводжують дію оплесками або сміхом. Однак потім дія переноситься з театру, супроводжуючи головного героя в його кампанії проти Франції: облозі Арфлер i битві при Азенкуре. Фільм завершується сватанням Генріха до французької принцеси Катерини, після чого персонажі знову опиняються в театрі.

Не рідко використовуються уривки з відомих опер. У цьому випадку об'єднуються елементи драматургії оперних сцен і фільму. У фільмі «П'ятий елемент» (Режисер: Люк Бессон. Музика: Ерік Серра) Дива Плавалагуна виконує оброблену версію apiї «Oh, giusto cielo! .. Il dolce suono» ( «O, праведне небо! .. Солодкий звук») з опери Гаетано Доніцетті «Лючія ді Ламмермур». Один 3 найдраматичніших епізодів фільму «Місія нездійсненна: Плем’я вигнанців» (Режисер: Крістофера МакКуоррі. Композитор: Джо Крэмер) відбувається в будівлі Віденської опери на постановці опери «Турандот» Джакомо Пучіні. У фільмі «Людина, яка плакала» режисер Саллі Поттер, використовує, у всій красі, музику з опер Жоржа Бізе.

У біографічних фільмах про музикантів даються уривки з їх творів, і тут вони фактично стають цитатами, але органічно пов'язаними з фабулою фільму. У цьому можна переконається на прикладах фільмів: «Великий вальс» американський музичний фільм 1938 р., поставлений режисером Жюльєном Дювів'є. Фільм біографічний і присвячений життю й творчості австрійського 
композитора й диригента Йоганна Штрауса, знаменитого «Короля вальсів». У «Великому вальсі» багато танців і музики Штрауса в обробці Дмитра Тьомкіна. Головну музичну роль зіграла і заспівала Міліца Кор'юс, яка емігрувала з СРСР; і «Переписуючи Бетховена» (Режисер: Агнешка Холланд. Музика: Людвига ван Бетховена) - історична мелодрама 2006 р. компанії Metro-Goldwyn-Mayer про останній рік життя композитора Людвіга ван Бетховена, роль якого виконав Ед Харріс. Фільм розкриває декілька епізодів бурхливого, суперечливого й трагічного життя Бетховена. Студентка Віденської консерваторії Анна Хольц, будучи асистенткою композитора Людвіга Ван Бетховена, допомагає йому в роботі над «Дев’ятою симфонією». Переносячи на нотний папір музику Бетховена, Ганна потрапляє в складний та дивний світ композитора, в якому натхнення супроводжують болісні страждання.

Питання про «музичну цитату» в кінофільмі відносне, воно залежить виключно від того, чи сприймає кіноглядач цитату як таку. Цитата стає цитатою лише в ту хвилину, коли глядач впізнає звідкіля вона, який сенс вона має, і що цим хотів сказати режисер. Якщо вона залишається невпізнаною, то вона функціонує просто як кіномузика, що пов'язана з кінокадром.

Наукова новизна дослідження в тому, що вперше сформуванні основні поняття застосування музичних цитат в кінофільмі та показано їх вплив на звукове вирішення кінофільму.

Теоретична значущість статті полягає в тому, що вона допомагає узагальнити інформацію про роль музичної цитати в кінофільмі, розповідає людям про щось нове, i сприяе розвитку музичної культури. Практична значущість дослідження полягає в тому, що воно може бути використане при музичному оформлені кінофільму та в програмах підготовки звукорежисерів.

Висновки. Вдаючись до цитування, композитор i режисер повинні подбати про те, щоб глядач їх упізнав; цитата привносить емоційні та смислові асоціації. У німому кіно музична ілюстрація, складена виключно з музичних цитат.

Музичні цитати можуть виконувати різноманітні функції: підкреслювати трагізм сцени, використовуватися як іронічний контраст, також цитата може бути застосована як драматичний елемент і музичний символ, може створювати пародію, характеризувати певний персонаж.

Аналіз матеріалу про цитату в фільмі дозволив автору сформувати систему понять про цитату в кіномузиці 3 обговоренням їх застосування, що має суттєве значення для практики звукового вирішення кінофільму. 


\section{Список використаних джерел}

1. Безклубенко С. Д. Мистецтво: терміни та поняття. В 2 т. Т. 2 / С. Д. Безклубенко. - Київ : Майстер-Принт, 2008. - 255 с.

2. Горпенко В. Г. Архітектоніка фільму : режисерські засоби і способи формування структури екранного видовища. В 5 т. Т. 3 Монтажна архітектоніка фільму. Ч. 2. Сюжетотворення. / В. Г. Горпенко ; Київ. держ. ін-т театрального мистецтва ім. І. К. Карпенка-Карого - Київ : ДІТМ, 2000. - 146 с.

3. Введение в экранную культуру: новые аудиовизуальные технологи : учеб. пособ. / отв. ред. К. С. Розлогов. - Москва : Искусство, 2005. - 480 с.

4. Лисса 3. Эстетика киномузыки : пер. с нем. / 3. Лиса. - Москва : Музыка, 1970. - 495 с.

5. Маньковський В. С. Основы звукооператорской роботы : учеб. пособие / В. С. Маньковський. - Москва : Искусство, 1984. - 240 с.

6. Рязанцев Л. В. Техніка лейтмотивів в кіномузиці / Л. В. Рязанцев // Вісн. КНУКіМ. Серія «Мистецтвознавство». - Київ, 2015.- Вип. 33. - С. 124-130.

7. Ейзенштейн С. М. Избранные произведения. В 5 т. Т. 2. Монтаж. / С. М. Ейзенштейн. - Москва : Искусство, 1964. - 549 с.

\section{References}

1. Bezklubenko, S. (2008). Art: terms and concepts. In vol. 2. vol. 2. Kyiv: Mayster-Print.

2. Eyzenshteyn, C. (1964). Selected Works. Installation.Moscow: Iskusstvo, vol. 2.

3. Horpenko, V. (2000). Architectonics of the film: directorial means and ways of forming the structure of the screen scenery. In $5 \mathrm{vol}$. Vol 3. Assembling architectonics of the film. Part 2. Plot creation. Kyiv: Kyiv State Institute named after I. Karpenko-Karyi.

4. Lissa, Z. (1970). Aesthetics of motion picture music. Moscow: Muzyka.

5. Mankovskiy, V. (1984). Fundamentals of Sound Operator Robots. Moscow: Iskusstvo.

6. Riazantsev, L. (2015). Technique of leitmotifs in cinematic music. Visnyk Kyivskoho natsionalnoho universytetu kultury $i$ mystetstv. Seriia «Mystetstvoznavstvo» [Bulletin of Kiev National University of Culture and Arts. Series «Art Studies»], issue 33, pp. 124-130.

7. Rozlogov, K. (Eds). (2005). Introduction to Screen Cultures: New Audiovisual Technologies. Moscow: Iskusstvo.

(C) Рязанщев Л. В., 2017 